Nevada

Environmental

Restoration

Project

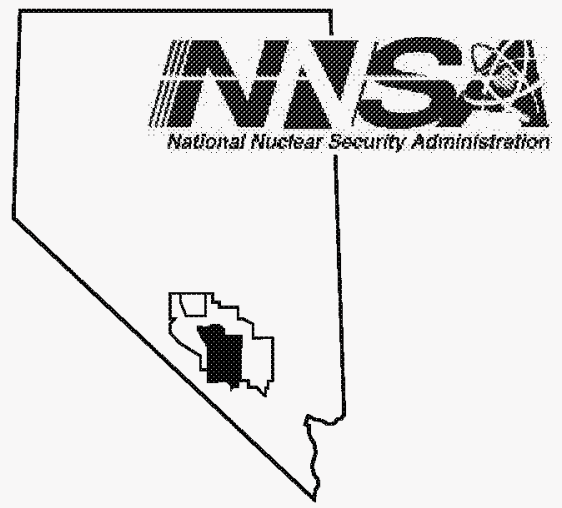

Corrective ActionPlan

ForCorrective ActionUnit516:

SepticSystemsandDischarge

Points,Nevada TestSite,Nevada

ControlledCopyNo.:

Revision:0

August2005

EnvironmentalRestoration

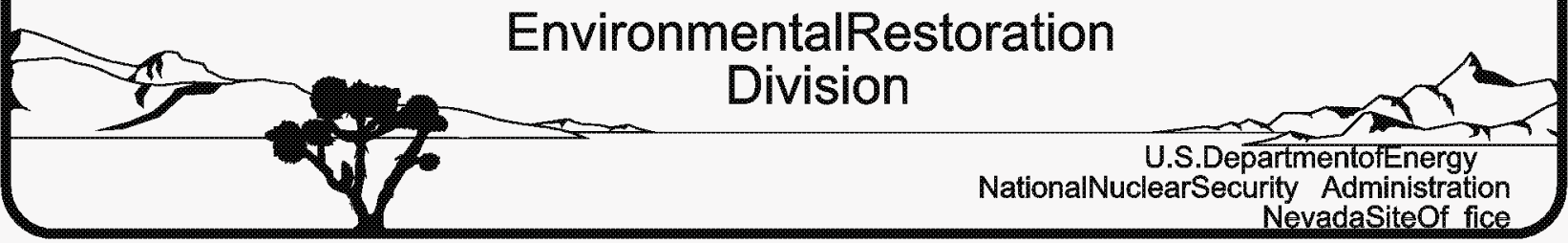




\title{
DISCLAIMER
}

This report was prepared as an account of work sponsored by an agency of the U.S. Government. Neither the U.S. Government nor any agency thereof, nor any of their employees, nor any of their contractors, subcontractors or their employees, makes any warranty or representation, express or implied, or assumes any legal liability or responsibility for the accuracy, completeness, or usefulness of any information, apparatus, product, or process disclosed, or represents that its use would not infringe privately own rights. Reference herein to any specific commercial product, process, or service by trade name, trademark, manufacturer, or otherwise, does not necessarily constitute or imply its endorsement, recommendation, or favoring by the U.S.

Government or any agency thereof. The views and opinions of authors expressed herein do not necessarily state or reflect those of the U.S. Government or any agency thereof.

This report has been reproduced directly from the best available copy.

Available for sale to the public from:

\author{
U.S. Department of Commerce \\ National Technical Information Service \\ 5285 Port Royal Road \\ Springfield, VA 22161-0002 \\ Telephone: (800) 553-6847 \\ Fax: (703) 605-6900 \\ E-mail: orders@ntis.gov \\ Online ordering: http://www.ntis.gov/ordering.htm
}

Available electronically at http://www.osti.gov/bridge.

Available for a processing fee to the U.S. Department of Energy and its contractors, in paper, from:

U.S. Department of Energy

Office of Scientific and Technical Information

P.O. Box 62

Oak Ridge, TN 37831-0062

Telephone: (865) 576-8401

Fax: (865) 576-5728

E-mail: reports@adonis.osti.gov 


\title{
CORRECTIVE ACTION PLAN FOR CORRECTIVE ACTION UNIT 516: SEPTIC SYSTEMS AND DISCHARGE POINTS NEVADA TEST SITE, NEVADA
}

\author{
U.S. Department of Energy \\ National Nuclear Security Administration \\ Nevada Site Office \\ Las Vegas, Nevada
}

Controlled Copy No.

Revision: 0

August 2005 
THIS PAGE INTENTIONALLY LEFT BLANK 


\section{CORRECTIVE ACTION PLAN FOR CORRECTIVE ACTION UNIT 516: SEPTIC SYSTEMS AND DISCHARGE POINTS, NEVADA TEST SITE, NEVADA}

Approved By:

SIGANTURE APPROVED

Date:

$8 / 03 / 05$

Sabine Curtis, Acting Project Manager

Industrial Sites Project

Approved By:

SIGANTURE APPROVED

Date: $\quad 8 / 03 / 05$

Janet Appenzeller-Wing, Acting Division Director

Environmental Restoration Division 
THIS PAGE INTENTIONALLY LEFT BLANK 


\section{TABLE OF CONTENTS}

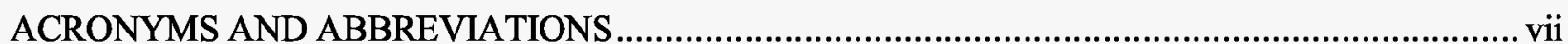

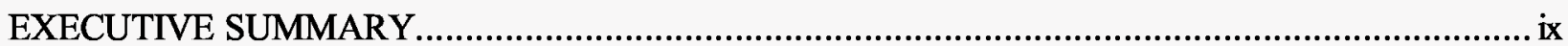

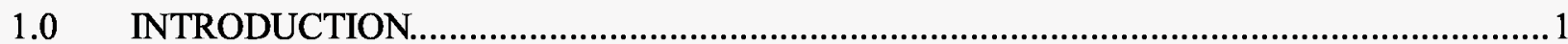

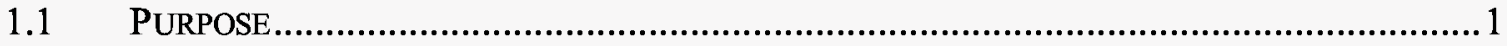

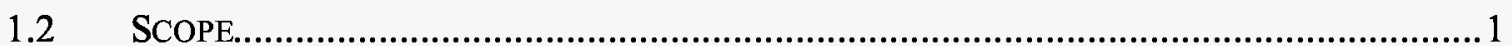

1.3 CORRECTIVE ACTION Plan CONTENTS....................................................................... 3

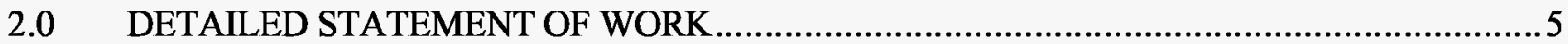

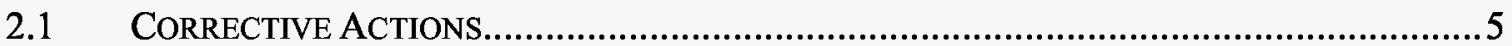

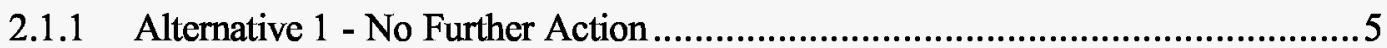

2.1.2 Alternative 2 - Clean Closure ................................................................. 5

2.2 CONSTRUCTION QUALITY ASSURANCE / QUALITY CONTROL ....................................... 12

2.2.1 Construction Field Sample Collection Activities............................................ 12

2.2.2 Construction Laboratory/Analytical Data Quality Indicators........................... 12

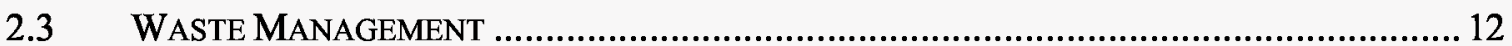

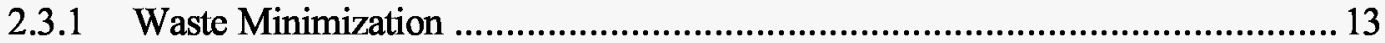

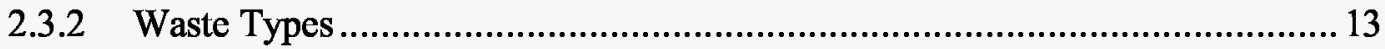

2.4 CONFIRMATION OF CORRECTIVE ACTIONS............................................................ 14

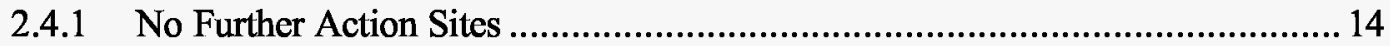

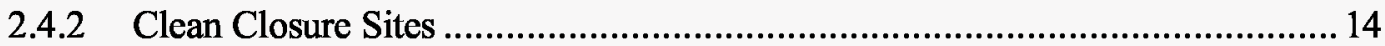

2.4.3 Sample Collection Methods ................................................................. 15

2.4.4 Laboratory/Analytical Data Quality Indicators ....................................... 15

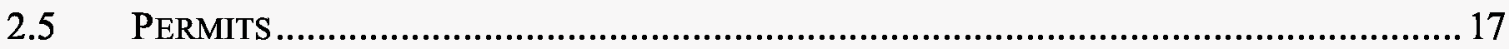

2.5.1 National Environmental Policy Act Checklist........................................... 17

2.5.2 NNSA/NSO Real Estate/Operations Permit ................................................... 17

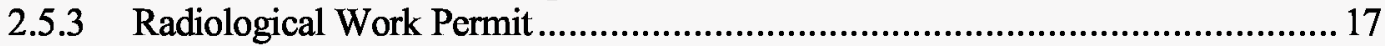

2.5.4 Utility Clearances, Excavation Permits, and Blind Penetration Permits ............ 17

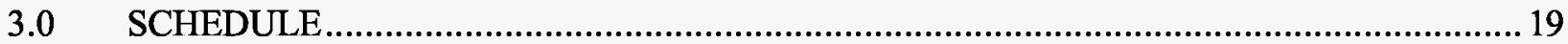

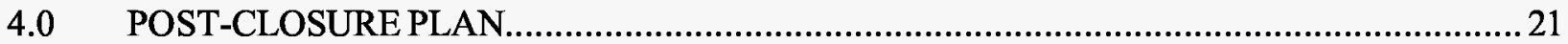

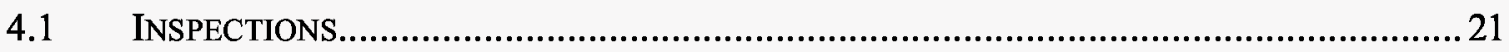

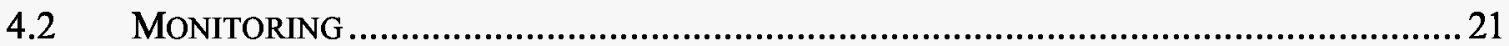

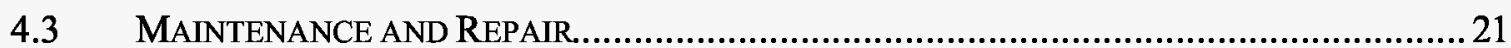

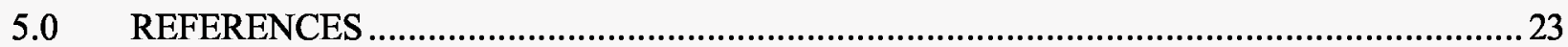

\section{FIGURES}

FIGURE 1. CAU 516 SITE LOCATION MAP ...................................................................

FIGURE 2. CAS 03-59-01, BUILDING 3C-36 SEPTIC S YSTEM...................................................6

FIGURE 3. CAS 03-59-02, BUILDING 3C-45 SEPTIC S YSTEM..................................................

FIGURE 4. CAS 06-51-01, SUMP AND PIPING AND CAS 06-51-03, ClEAN-OUT 


\section{TABLE OF CONTENTS (continued)}

\section{APPENDICES}

APPENDIX A.1 Engineering Specifications and Drawings ........................................... A.1-1

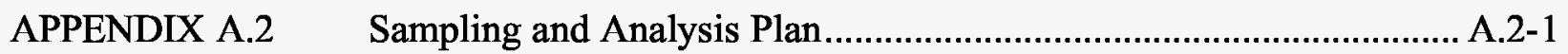

APPENDIX A.3 Project Organization.....................................................................

LIBRARY DISTRIBUTION LIST 


\section{ACRONYMS AND ABBREVIATIONS}

$\begin{array}{ll}\text { BMP } & \text { best management practice } \\ \text { BN } & \text { Bechtel Nevada } \\ \text { CADD } & \text { Corrective Action Decision Document } \\ \text { CAIP } & \text { Corrective Action Investigation Plan } \\ \text { CAP } & \text { Corrective Action Plan } \\ \text { CAS } & \text { Corrective Action Site(s) } \\ \text { CAU } & \text { Corrective Action Unit(s) } \\ \text { COC } & \text { contaminant(s) of concern } \\ \text { CR } & \text { Closure Report } \\ \text { DOE } & \text { U.S. Department of Energy } \\ \text { DQI } & \text { Data Quality Indicator(s) } \\ \text { DQO } & \text { Data Quality Objective(s) } \\ \text { DRO } & \text { dieselrange organics } \\ \text { EPA } & \text { U.S. Environmental Protection Agency } \\ \text { FFACO } & \text { Federal Facility Agreement and Consent Order } \\ \text { ft } & \text { foot (feet) } \\ \text { gal } & \text { gallon } \\ \text { in. } & \text { inch } \\ \text { ISOCS } & \text { In-Situ Object Counting System } \\ \text { LLW } & \text { low-level waste } \\ \text { mg/L } & \text { milligram per liter } \\ \text { mg/kg } & \text { milligrams per kilogram } \\ \text { mrem/yr } & \text { millirem per year } \\ \text { NAC } & \text { Nevada Administrative Code } \\ \text { NCRP } & \text { National Council on Radiation Protection and Measurements } \\ \text { NDEP } & \text { Nevada Division of Environmental Protection } \\ \text { NEPA } & \text { National Environmental Policy Act } \\ \text { NNSA/NSO } & \text { U.S. Department of Energy, National Nuclear Security Administration } \\ \text { NTS } & \text { Nevada Site Office } \\ \text { OI } & \text { Nevada Test Site } \\ \text { OP } & \text { Organization Instruction } \\ \% \text { p } & \text { Organization Procedure } \\ \text { PAL } & \text { percent recovery } \\ \text { pCi/g } & \text { Preliminary Action Level } \\ \text { pCi/L } & \text { picoCuries per gram } \\ \text { PPE } & \text { picoCuries per liter } \\ \text { Pu } & \text { personal protective equipment } \\ \end{array}$




\section{ACRONYMS AND ABBREVIATIONS (continued)}

QA/QC

RPD

REOP

RWP

TCLP

TPH

TSD

VCP

VOC

WGS

$\mathrm{yd}^{3}$
Quality Assurance/Quality Control

relative percentage difference

Real Estate/Operations Permit

Radiological Work Permit

Toxicity Characteristic Leaching Procedure

total petroleum hydrocarbons

treatment, storage, and disposal

vitrified clay pipe

volatile organic compounds

Waste Generator Services

cubic yard(s) 


\section{EXECUTIVE SUMMARY}

Corrective Action Unit (CAU) 516: Septic Systems and Discharge Points, is listed in the Federal Facility Agreement and Consent Order of 1996. CAU 516 consists of six Corrective Action Sites (CASs) located in Areas 3, 6, and 22 of the Nevada Test Site (NTS), which is located approximately 65 miles northwest of Las Vegas, Nevada. CAU 516 is comprised of the following six CASs:

- 03-59-01 Building 3C-36 Septic System

- 03-59-02 Building 3C-45 Septic System

- 06-51-01 Sump and Piping

- 06-51-02 Clay Pipe and Debris

- 06-51-03 Clean-Out Box and Piping

- 22-19-04 Vehicle Decontamination Area

Site characterization of the CAU 516 CASs was performed in 2003 and early 2004 and the results are presented in the CAU 516 Corrective Action Decision Document (CADD) (U.S. Department of Energy, National Nuclear Security Administration Nevada Site Office [NNSA/NSO], 2004). Briefly, the results of the site characterization and the scope of work required to implement the recommended closure alternatives include the following:

- CAS 03-59-01, Building 3C-36 Septic System includes a septic tank, distribution box, leachfield, and associated piping. The tank contained total petroleum hydrocarbon (TPH) diesel-range organics (DRO) above the TPH Preliminary Action Level (PAL). The other septic system components were not contaminated.

The CAS will be clean closed by removing, solidifying, and disposing approximately 1,430 gallons (gal) of liquid and solid waste from the septic tank. The septic tank will be removed and disposed of as hydrocarbon waste. As a best management practice (BMP), the distribution box and a 10-foot ( $\mathrm{ft}$ ) section of pipe running between the septic tank and distribution box will be removed and disposed of as construction debris. The open ends of piping that have the potential to receive media will be sealed.

- CAS 03-59-02, Building 3C-45 Septic System includes a septic tank, distribution box, associated piping, leachfield, and two dry wells. The tank contained TPH-DRO above the PAL, gross alpha and gross beta above the recommended levels for lagoon disposal, and chlorinated compounds above hazardous waste limits. The other septic sys tem components were not contaminated.

The CAS will be clean closed by removing and disposing approximately 714 gallon of liquid and solid waste from the septic tank, and removing and disposing the septic tank. The distribution box, dry wells, and piping are not contaminated, but as a BMP, the distribution box will be removed and disposed of as construction debris. The CADD identified approximately 35 cubic yards $\left(\mathrm{yd}^{3}\right)$ of plutonium $(\mathrm{Pu})-239$ contaminated soil to be removed 


\section{EXECUTIVE SUMMARY (continued)}

from the leachfield (NNSA/NSO, 2004). Because the Pu-239 PAL has been revised upward, this soil will no longer be removed and a Record of Technical Change to revise the CAU 516 CADD has been submitted for approval. The dry well north of the leachfield will be excavated to a depth of $12 \mathrm{ft}$ below ground surface and materials disposed of appropriately. The dry well east of the building foundation will be excavated to $10 \mathrm{ft}$ below ground surface and materials disposed of appropriately.

- CAS 06-51-01, Sump and Piping includes an 82- $\mathrm{ft}$ long section of pipe that is part of the $275 \mathrm{ft}$ of piping located between Building 660 and the sump. The ends of this section of pipe contained soil/sediment contaminated with TPH-DRO above the PAL. The other septic system components were not contaminated. The CAS will be clean closed by removing approximately $82 \mathrm{ft}$ of TPH-contaminated piping running between Building 660 (part of $275 \mathrm{ft}$ of pipe) and the sump, and disposing the piping as appropriate.

- CAS 06-51-02, Clay Pipe and Debris included only surface debris; therefore, sampling was not required. The surface debris was surveyed, removed, and appropriately disposed in the NTS Area 9 U10c Landfill. Because no environmental waste or concerns remain, this CAS will be closed by taking no further action.

- CAS 06-51-03, Clean-Out Box and Piping includes a clean-out box containing approximately $0.5 \mathrm{yd}^{3}$ of material contaminated with TPH-DRO above the PAL. The CAS will be clean closed by removing approximately $0.5 \mathrm{yd}^{3}$ of the TPH-contaminated solid material from the clean-out box, removing the clean-out box, and disposing appropriately. As a BMP, the associated piping including a $20-\mathrm{ft}$ section of pipe that extends west from the clean-out box and the 5- $\mathrm{ft}$ section of pipe between the clean-out box and Building 660 foundation will be removed.

- CAS 22-19-04, Vehicle Decontamination Area was identified as having no contaminants of concern, and will therefore, be closed by taking no further action. 


\subsection{INTRODUCTION}

Corrective Action Unit (CAU) 516, Septic Systems and Discharge Points, is listed in the Federal Facility Agreement and Consent Order (FFACO) of 1996 (FFACO, 1996). CAU 516 consists of six Corrective Action Sites (CASs) located in Areas 3, 6, and 22 of the Nevada Test Site (NTS), which is located approximately 65 miles northwest of Las Vegas, Nevada (Figure 1). CAU 516 is comprised of the following six CASs:

- 03-59-01 Building 3C-36 Septic System

- 03-59-02 Building 3C-45 Septic System

- 06-51-01 Sump and Piping

- 06-51-02 Clay Pipe and Debris

- 06-51-03 Clean-Out Box and Piping

- 22-19-04 Vehicle Decontamination Area

Details on site history and site characterization results for CAU 516 are provided in the approved Corrective Action Investigation Plan (CAIP), (U.S. Department of Energy, National Nuclear Security Administration Nevada Site Office [NNSA/NSO], 2003), and the approved Corrective Action Decision Document (CADD) (NNSA/NSO, 2004).

\subsection{PURPOSE}

CAU 516 consists of six CASs located in Areas 3, 6, and 22 of the NTS that were characterized in 2003 according to the approved CAIP (NNSA/NSO, 2003). The results of the site characterization are reported in the CAU 516 CADD (NNSA/NSO, 2004).

The purpose of this Corrective Action Plan (CAP) is to provide the detailed scope of work required to implement the recommended corrective actions as specified in the approved CAU 516 CADD (NNSA/NSO, 2004).

\subsection{SCOPE}

The results of the site characterization and the scope of work required to implement the recommended corrective action as stated in the CAU 516 CADD (NNSA/NSO, 2004) are briefly discussed below.

CAS 03-59-01, Building 3C-36 Septic System, is located in the former Area 3 Camp south of Road 3-01 and consists of a septic tank, distribution box, leachfield, and associated piping that supported the operation of Building 3C-36. Results of the characterization reported total petroleum hydrocarbons (TPH) as diesel range organics (DRO) as the only contaminant of concern (COC) present. The CAS will be clean closed by solidifying and removing the contents of the septic tank, removing the concrete septic tank, and, as a best management practice (BMP), removing the distribution box and 10 feet $(\mathrm{ft})$ of associated piping. Also as a BMP, all open pipes left in place that have a potential to receive media will be sealed. All excavations will be backfilled with native material. 


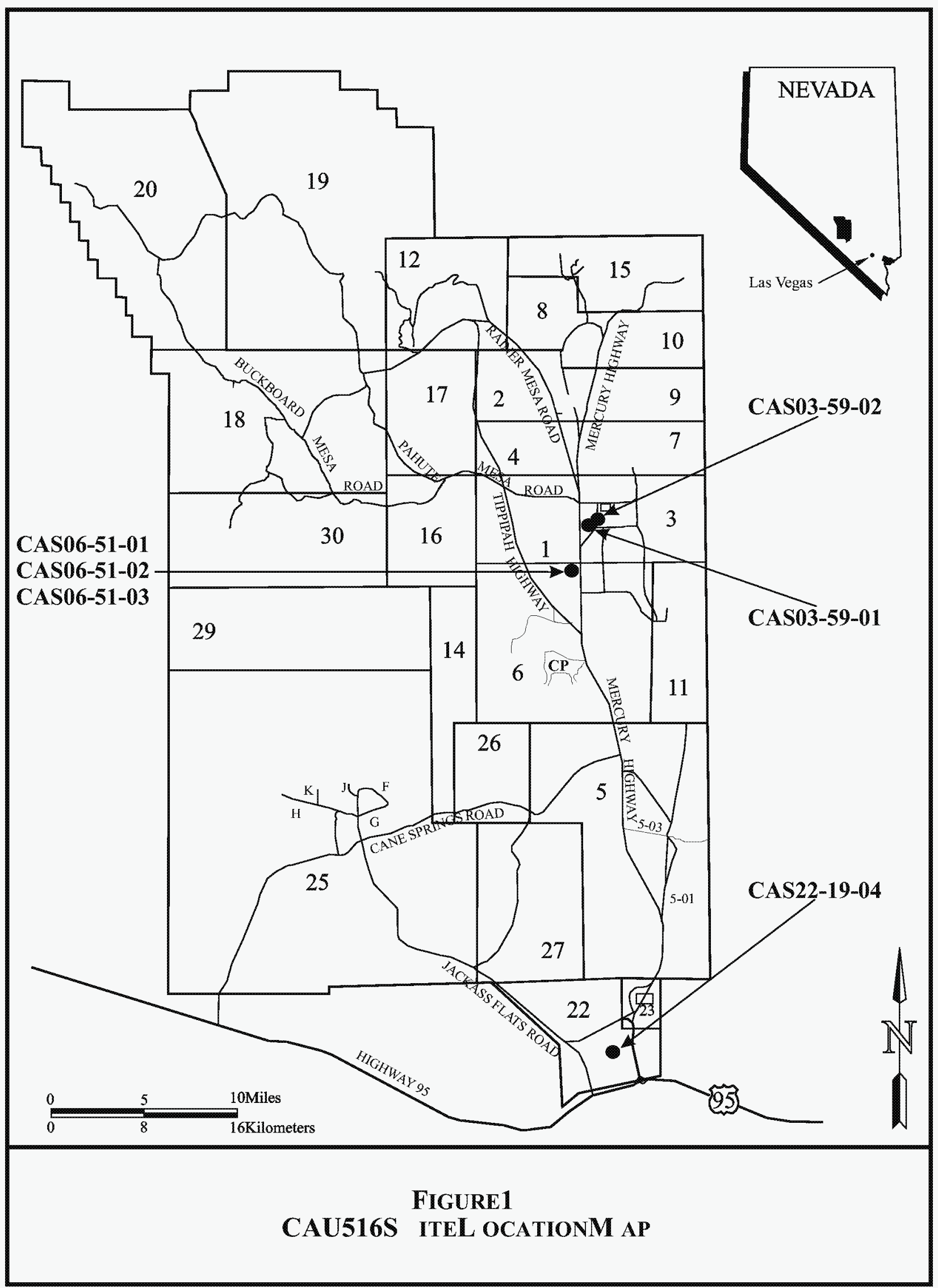


CAS 03-59-02, Building 3C-45 Septic System, is located north of Road 3-01 and west of Angle Road in Area 3. It consists of a septic tank, distribution box, leachfield, two dry wells, and associated piping that serviced Building $3 \mathrm{C}-45$. Results of the characterization reported Plutonium (Pu)-239 impacted soil in the leachfield, hazardous waste and TPH in the influent chamber of the tank, and TPH and elevated levels of gross alpha and gross beta in the effluent chamber of the tank. The CAS will be cleaned closed by solidifying and removing the contents of the septic tank, removing the septic tank, and as a BMP, removing the dry wells, distribution box 10- $\mathrm{ft}$ section of pipe between the septic tank and distribution box, and sealing all open pipes left in place that have a potential to receive media. All excavations will be backfilled with native material. Due to the revised Pu-239 PAL, soil identified for removal from the leachfield will not be removed, and a Record of Technical Change to the CADD stating such has been submitted for approval.

CAS 06-51-01, Sump and Piping, is located in the Area 6 Well 3 Yard, and includes a sump and the associated piping running to the collection box adjacent to Building 660 . The sump is filled with soil. Results of the characterization reported TPH-DRO as the only COC present within an 82- $\mathrm{ft}$ section of the pipe located about $37 \mathrm{ft}$ south of the sump. The CAS will be clean closed by removing approximately $82 \mathrm{ft}$ of pipe running between Building 660 and the sump. As a BMP, all open pipes left in place that have a potential to receive media will be sealed. All excavations will be backfilled with native material.

CAS 06-51-02, Clay Pipe and Debris, is a housekeeping CAS that consisted of a variety of surface debris. All debris was screened for radioisotopes, removed, and disposed of at the Area 9 U10c Landfill as part of the site characterization activities (NNSA/NSO, 2004). Therefore, this CAS will be closed by taking no further action.

CAS 06-51-03, Clean-Out Box and Piping, consists of a clean-out box on the north side of the building and piping coming into the clean-out box from the west. Results of the characterization reported TPH-DRO as the only COC present in the soil in the clean-out box. This CAS will be clean closed by removing contaminated solid from the clean-out box and removing the clean-out box. As a BMP, a 20 - $\mathrm{ft}$ section of pipe that extends west from the clean-out box and the section of pipe between the clean-out box and Building 660 foundation will be removed. All open pipes left in place that have a potential to receive media will be sealed. All excavations will be backfilled with native material.

CAS 22-19-04, Vehicle Decontamination Area, is a former vehicle decontamination area located approximately $800 \mathrm{ft}$ southwest of the Weather Station in Area 22. It consists of a decontamination pad, a drainage ditch, and a sump. No COCs were detected at this site and, therefore this CAS will be closed by taking no further action.

\subsection{Corrective ACtion Plan Contents}

This CAP is comprised of the following sections and appendices:

- Section 1.0

Introduction

- Section 2.0

Detailed Statement of Work

- Section 3.0

Schedule 
- Section 4.0 Post-Closure Plan

- Section $5.0 \quad$ References

- Appendix A.1 Engineering Specifications and Drawings

- Appendix A.2 Sampling and Analysis Plan

- Appendix A.3 Project Organization

- Library Distribution List

Appendix A.1 is included in this CAP as required by the approved FFACO CAP outline, but contains no material because engineering specification or drawings are not necessary for site closure. Similarly, Appendix A.2 is included as required but contains no material, because Sections 2.1.2 and 2.4 provide sufficient sampling detail.

This report was primarily developed using information and guidance from the following documents:

- Federal Facility Agreement and Consent Order (FFACO, 1996)

- Corrective Action Investigation Plan for Corrective Action Unit 516 (NNSA/NSO, 2003)

- Corrective Action Decision Document for Corrective Action Unit 516 (NNSA/NSO, 2004) 


\subsection{DETAILED STATEMENT OF WORK}

Three Corrective Action alternatives for CAU 516 were evaluated and identified in the CADD (NNSA/NSO, 2004).

Alternative 1 - No Further Action

Alternative 2 - Clean Closure

Alternative 3 - Close in Place with Administrative Controls

The approved Corrective Actions for the CAU 516 CASs include:

- CAS 03-59-01, Clean Closure

- CAS 03-59-02, Clean Closure

- $\quad$ CAS 06-51-01, Clean Closure

- CAS 06-51-02, No Further Action

- CAS 06-51-03, Clean Closure

- CAS 22-19-04, No Further Action

\subsection{CORRECTIVE ACTIONS}

The corrective action alternatives for CAU 516 were identified in the CADD (NNSA/NSO, 2004) and approved by the Nevada Division of Environmental Protection (NDEP). The objective of the corrective actions is to prevent or mitigate adverse environmental impacts due to exposure and migration of surface and subsurface waste. The corrective actions for CAU 516 are identified below.

\subsubsection{Alternative 1 - No Further Action}

No Further Action is the approved corrective action for the following CASs.

CAS 06-51-02: Clay Pipe and Debris. Housekeeping debris was removed during the corrective action investigation; no environmental waste or concerns remain.

CAS 22-19-04: Vehicle Decontamination Area. No COC were identified at this CAS during site characterization.

\subsubsection{Alternative 2 - Clean Closure}

Clean Closure is the approved corrective action for the following CASs.

CAS 03-59-01: Building 3C-36 Septic System. CAS 03-59-01 consists of a septic tank, distribution box, leachfield, and associated piping that supported the operation of Building 3C-36 (Figure 2). The septic tank has a capacity of 3,000 gallons (gal) and contains approximately 1,430 gal of liquid and solid waste in both the influent and effluent chambers of the tank. Media from the septic tank was screened for fecal coliform prior to sampling during site characterization. All the results were negative. Results indicate that TPH-DRO is present in the septic tank solid contents. The solids in the influent and effluent chambers contained 3,600 milligrams per kilogram $(\mathrm{mg} / \mathrm{kg}$ ) and 7,800 mg/kg TPH-DRO, respectively 


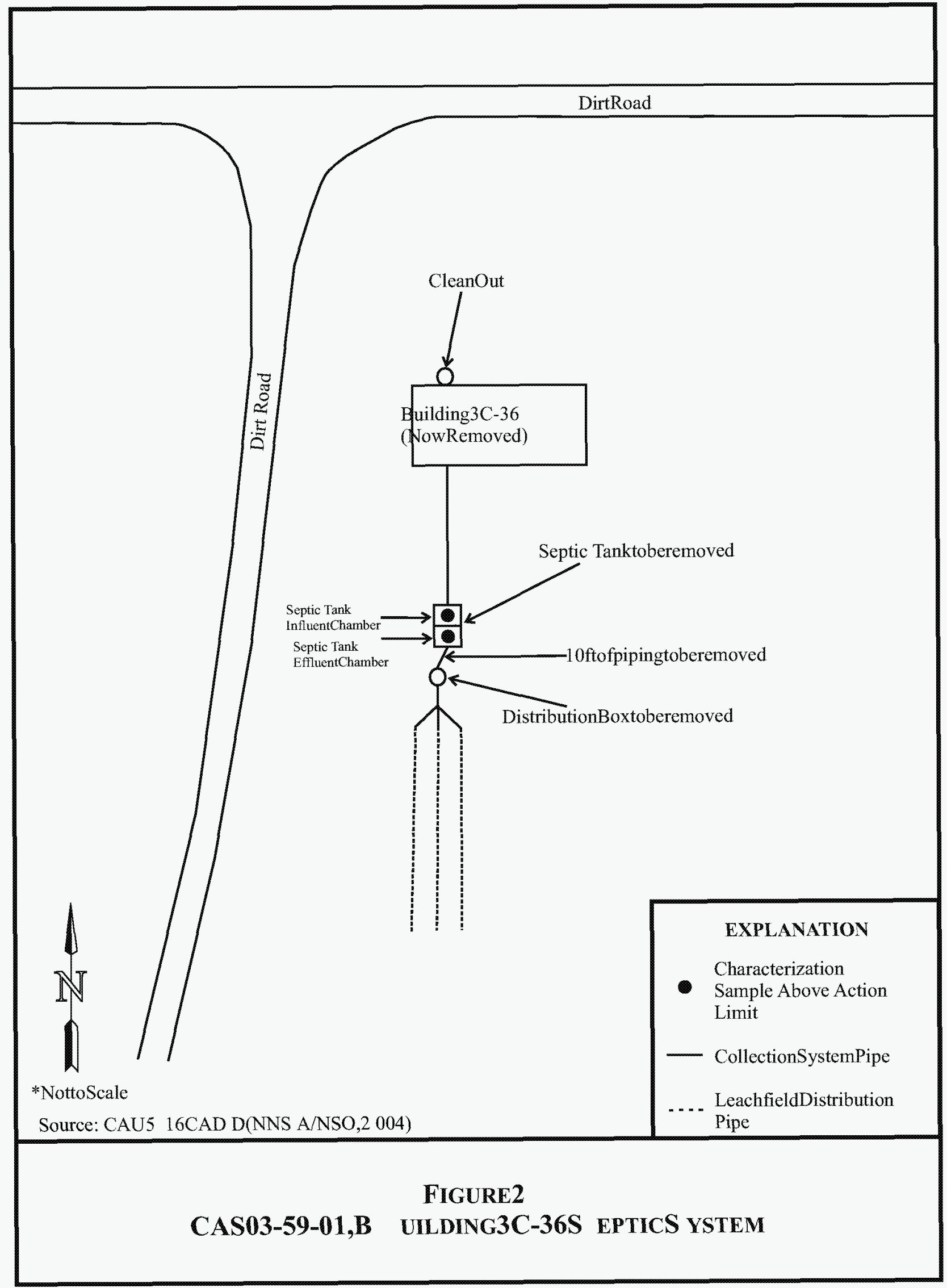


(NNSA/NSO, 2004). The waste exceeds the State of Nevada TPH action level of $100 \mathrm{mg} / \mathrm{kg}$ as stated in the Nevada Administrative Code (NAC) 445A.2272 for petroleum hydrocarbons (NAC, 2003).

The top of the septic tank will be exposed and removed as necessary. Because the septic tank reportedly contains approximately 1,430 gal of liquid and solid waste, a portion of the liquid from the septic tank will be pumped into a lined basin and solidified with NTS native fill. The remainder of the septic tank contents will be solidified in the tank with NTS native fill and mixed using the appropriate heavy equipment. A waste characterization sample(s) will be collected from the solidified septic tank and basin waste and analyzed for gamma-emitting radionuclides by either an In-situ Object Counting System (ISOCS) or laboratory analysis.

Upon receipt of analytical results, the waste will be disposed in an appropriate onsite disposal facility. The tank will be removed from the ground by the appropriate equipment and disposed of as hydrocarbon waste in an appropriate onsite disposal facility. After removal of the tank, visual inspection will be conducted to ensure that visible contamination has been removed. Prior to collecting verification samples, field screening for TPH will be performed using a PetroFLAG ${ }^{\mathbb{Q}}$ kit. After field screening indicates that contamination is no longer present above PALs, a minimum of five soil verification samples will be collected from excavation, at least one from each side wall and one from the base of the excavation. Samples will be analyzed for TPH-DRO to verify that TPH-DRO has not been released to the surrounding soil. NTS native fill will be used to backfill the excavation after the removal of CAS components and analytical results verify no COC remain onsite at levels greater than PALs.

If not feasible to remove the tank from the ground, the site will be clean closed by removing, analyzing, and disposing the waste as stated above. After removal of the tank contents, the septic tank interior will be pressure washed/steam cleaned, and rinsed to remove any removable scale or residual material The initial rinse water will be pumped from the septic tank, solidified, and disposed as hydrocarbon waste in an appropriate onsite disposal facility. A sample of final rinse water will be collected from the septic tank and analyzed for TPHDRO for verification purpose. If analytical results of final rinse water indicate contamination of TPH-DRO in excess of regulatory guidelines, additional cleaning and rinsing will be completed until acceptable analytical results are obtained. The empty tank will be backfilled with NTS native fill.

The distribution box, leachfield, and piping are not contaminated. As a BMP, the distribution box and a 10- $\mathrm{ft}$ section of pipe between the septic tank and distribution box will be removed and disposed of as construction debris. The ends of any remaining piping having the potential to receive media will be sealed. NTS native fill will be used to backfill excavations.

CAS 03-59-02: Building 3C-45 Septic System. CAS 03-59-02 is comprised of $215 \mathrm{ft}$ of collection system piping that received effluent from the drains at the former Building $3 \mathrm{C}-45$, a septic tank located east of the building foundation, a distribution box and piping, a leachfield, and two dry wells (Figure 3). The septic tank has a capacity of approximately 1,200 gal and contains approximately 714 gal of liquid and solid waste in both the chambers of septic tank. The influent and effluent chambers of the septic tank contain approximately 169 gal and 545 gal of liquid and solid waste, respectively (NNSA/NSO, 2004). Media from the septic tank was screened for fecal coliform prior to sampling during site characterization All the results were negative. 
Dry Well

tobeexcavated

andclosed

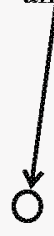

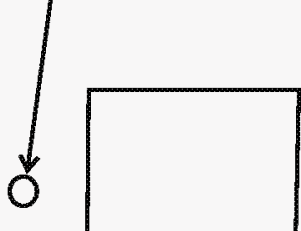

Building3C-45

Foundation

Areaidentifiedas

Plutonium-239impactedsoil

(35yd ${ }^{3}$ )belowP ALsand

willbeleftinplace.

DistributionBox

toberemoved
PhotoProcessing

Dry Well tobeexcavated andclosed
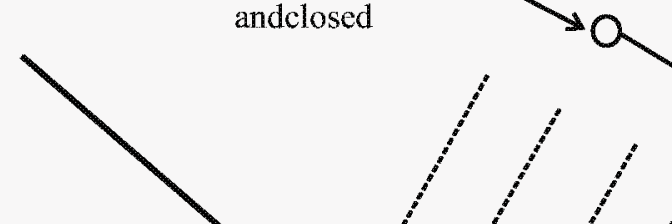
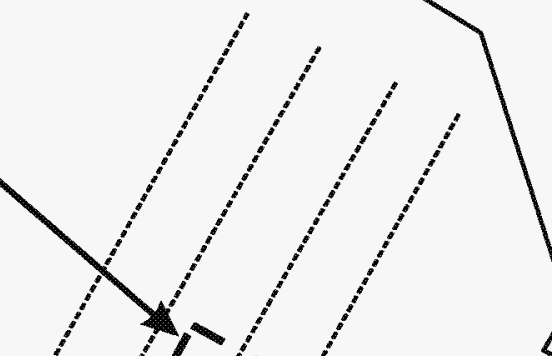

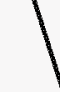
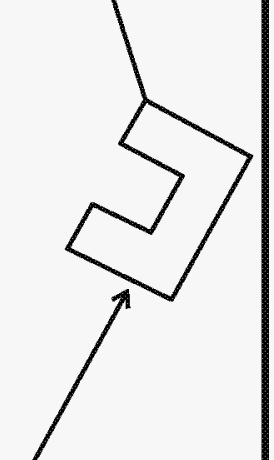

FormerLocationofMobile PhotoProcessing Trailers (ConcretePadsRemain)

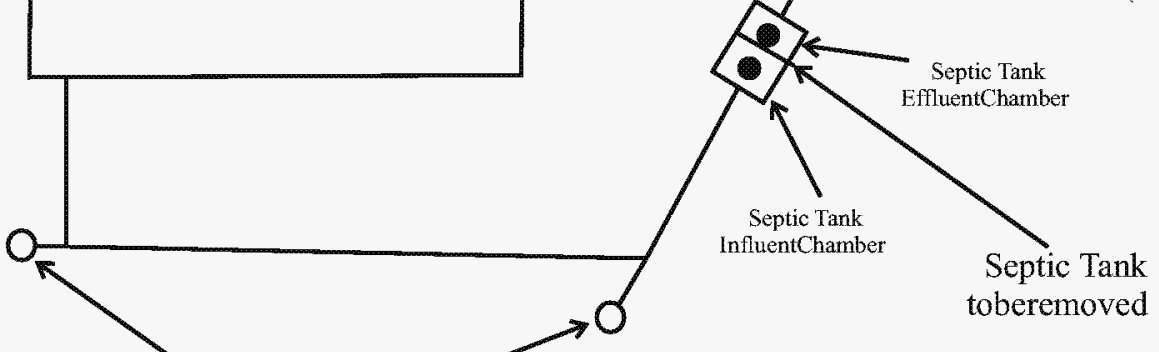

EXPLANATION

- Characterization

Sample Above Action Limit

CollectionSystemPipe

... - LeachfieldDistribution Pipe

Source: CAU5 16CAD D(NNS A/NSO,2 004)

FIGURE3

CAS03-59-02,B UILDING3C-45S EPTICS YSTEM 
The solids in the influent chamber contained $28,000 \mathrm{mg} / \mathrm{kg}$ TPH-DRO, exceeding the action level of $100 \mathrm{mg} / \mathrm{kg}$ (NAC, 2003). The solids also contained 6 milligrams per liter $(\mathrm{mg} / \mathrm{L})$ of 1,1-dichloroethene, $0.96 \mathrm{mg} / \mathrm{L}$ of 1,2-dichloroethane, and $4 \mathrm{mg} / \mathrm{L}$ of trichloroethene, exceeding the Toxicity Characteristic Leaching Procedure (TCLP) regulatory levels for hazardous waste (U.S. Code of Federal Regulations, 2002). The solids in the effluent chamber contained $7,900 \mathrm{mg} / \mathrm{kg}$ of TPH-DRO, exceeding the action level of $100 \mathrm{mg} / \mathrm{kg}$ (NAC, 2003), while the liquid phase contained gross alpha $(104 \pm 20$ picoCuries per liter $[\mathrm{pCi} / \mathrm{L}])$ and gross beta (193 $\pm 34 \mathrm{pCi} / \mathrm{L})$, exceeding recommended levels for sewage lagoon disposal (NDEP, 2005).

Based on the CADD (NNSA/NSO, 2004) site characterization data, additional waste characterization samples need to be collected from the septic tank and analyzed before cleanup activities can commence. Two samples (liquid and sludge) will be collected from each chamber and analyzed for TCLP-volatile organic compounds (VOCs), gamma-emitters, isotopic plutonium, and isotopic uranium. Depending on the analytical results, the contents of the chambers may be segregated to reduce the possibility of mixing different waste streams.

If results indicate that a waste stream is a mixed (hazardous and radiological) waste, then the contents will be removed from the septic tank and solidified with an appropriate solidification agent or solidified in the septic tank with an appropriate solidification agent and then removed. The waste will be packaged in an appropriate container. A waste profile will be completed for the septic tank waste by Bechtel Nevada (BN) Waste Generator Services (WGS). Once a waste profile is completed and approved, the waste will be disposed of at an appropriate permitted treatment, storage, and disposal (TSD) facility.

If results indicate that TCLP-VOCs are below the hazardous waste criteria, then contents of the waste can be solidified with NTS native fill. Because the septic tank contains approximately 714 gal of liquid and solid waste, a portion of the liquid from the septic tank will be pumped into a lined basin and solidified with NTS native fill. The remainder of the septic tank contents will be solidified with NTS native fill and mixed using the appropriate equipment. $A$ waste characterization sample will be collected from the solidified waste and analyzed for radiological constituents by laboratory analysis. Upon receipt of analytical results, the waste will be disposed at an appropriate onsite disposal facility. The tank will be removed from the ground by the appropriate equipment and disposed of as hydrocarbon waste in an appropriate onsite disposal facility. After removal of the tank, visual inspection will be conducted to ensure that visible contamination has been removed. Prior to collecting verification samples, field screening for TPH will be performed using a PetroFL $\Lambda G^{\circledR}$ kit. $\Lambda$ fter field screening indicates that contamination is no longer present above PALs, a minimum of five soil verification samples will be collected from the excavation, at least one from each side wall and one from the base of the excavation. Samples will be analyzed for TPH-DRO and any additional COC identified to verify that COC have not been released to the surrounding soils.

If it is not feasible to remove the septic tank from the ground, the site will be clean closed by removing, analyzing, and disposing the waste in an appropriate disposal facility. After removal of the tank contents, the interior of septic tank will be pressure washed/steam cleaned and rinsed to remove any removable scale or residual material The initial rinse water will be pumped from the septic tank, solidified, and disposed in an appropriate disposal facility. For verification purposes, a sample of final rinse water will be collected from the septic tank and analyzed for any $\mathrm{COC}$ identified. If analytical results of the final rinse water indicate $\mathrm{COC}$ in excess of 
regulatory guidelines, additional cleaning and rinsing will be completed until acceptable analytical results are obtained. The empty tank will be backfilled with NTS native fill. The CADD states that approximately 35 cubic yards $\left(\mathrm{yd}^{3}\right)$ of $\mathrm{Pu}-239$ contaminated soil at will be removed from leachfield location B06 (Figure 3). This action is based on a Pu-239 PAL of $7.62 \mathrm{pCi} / \mathrm{g}$ based on a $15 \mathrm{mrem} / \mathrm{yr}$ dose. The Pu-239 PAL has been revised upward to $12.7 \mathrm{pCi} / \mathrm{g}$ based on a $25 \mathrm{mrem} / \mathrm{yr}$ dose and NDEP has approved use of revised radiological PAL (NDEP, 2004 and National Council on Radiation Protection and Measurements [NCRP], 1999). Therefore, the leachfield soil does not exceed the revised Pu-239 PAL and will not be removed. A "Record of Technical Change" to the CADD has been submitted for approval, recommending the Pu-239 impacted soil in the leachfield be left in place.

The distribution box and piping are not contaminated. As a BMP, the distribution box will be removed and disposed as construction debris. NTS native fill will be used to backfill excavations. The ends of any remaining piping that have the potential to receive media will be sealed.

The dry well north of the leachfield will be excavated to $12 \mathrm{ft}$ below ground surface. The dry well east of the building foundation will be excavated to $10 \mathrm{ft}$ below ground surface. Material removed from the dry wells will be disposed of as onsite non-impacted debris. NTS native fill will be used to backfill excavations.

CAS 06-51-01: Sump and Piping. CAS 06-51-01 consists of a sump and associated piping runs to the collection box, which is adjacent to Building 660 (Figure 4). The sump measures 40 by $50 \mathrm{ft}$ by approximately $10 \mathrm{ft}$ deep, and is surrounded with a 3-strand barbwire fence. It includes $275 \mathrm{ft}$ of vitrified clay pipe (VCP) running between the collection box (CAS 06-51-03) and the outfall into the sump. A $220-\mathrm{mg} / \mathrm{kg}$ concentration of TPH-DRO was detected in a soil sample composited from both ends of the $82 \mathrm{ft}$ pipe segment. The soil sample exceeded the State of Nevada TPH action level of $100 \mathrm{mg} / \mathrm{kg}$ (NAC, 2003). The contamination is contained within the pipe and the volume of soil in the pipe is approximately $1 \mathrm{yd}^{3}$. Approximately $82 \mathrm{ft}$ of contaminated piping running between Building 660 (part of $275 \mathrm{ft}$ of pipe) and the sump will be removed and disposed as hydrocarbon-impacted waste in an appropriate onsite disposal facility. $\Lambda$ fter removal of the piping, visual inspection will be conducted to ensure that visible contamination has been removed. Prior to collecting verification samples, field screening for TPH will be performed using a PetroFLAG ${ }^{\circledR}$ kit. After field screening indicates that contamination is no longer present above PALs, verification soil samples will be collected from the soil beneath the pipe at 15 -foot intervals. Samples will be analyzed for TPH-DRO to verify that TPH-DRO has not been released in the soil. After analytical results verify the pipe excavation is clean of TPH, NTS native fill will be used to backfill excavations.

CAS 06-51-03: Clean-Out Box and Piping. CAS 06-51-03 consists of a clean-out box on the north side of the building and piping coming into the clean-out box from the west (Figure 4). The clean-out measures 2 by $2 \mathrm{ft}$ by 3 -in. thick. The clean-out box is located a few feet from the north side of the building. There is a 4-in. VCP that extends into the box from the west. Another 4-in. clay pipe enters the bottom of the box from the building and exits to the north, extending $275 \mathrm{ft}$ to the sump (CAS 06-51-01). TPH-DRO was found in the sample collected from 


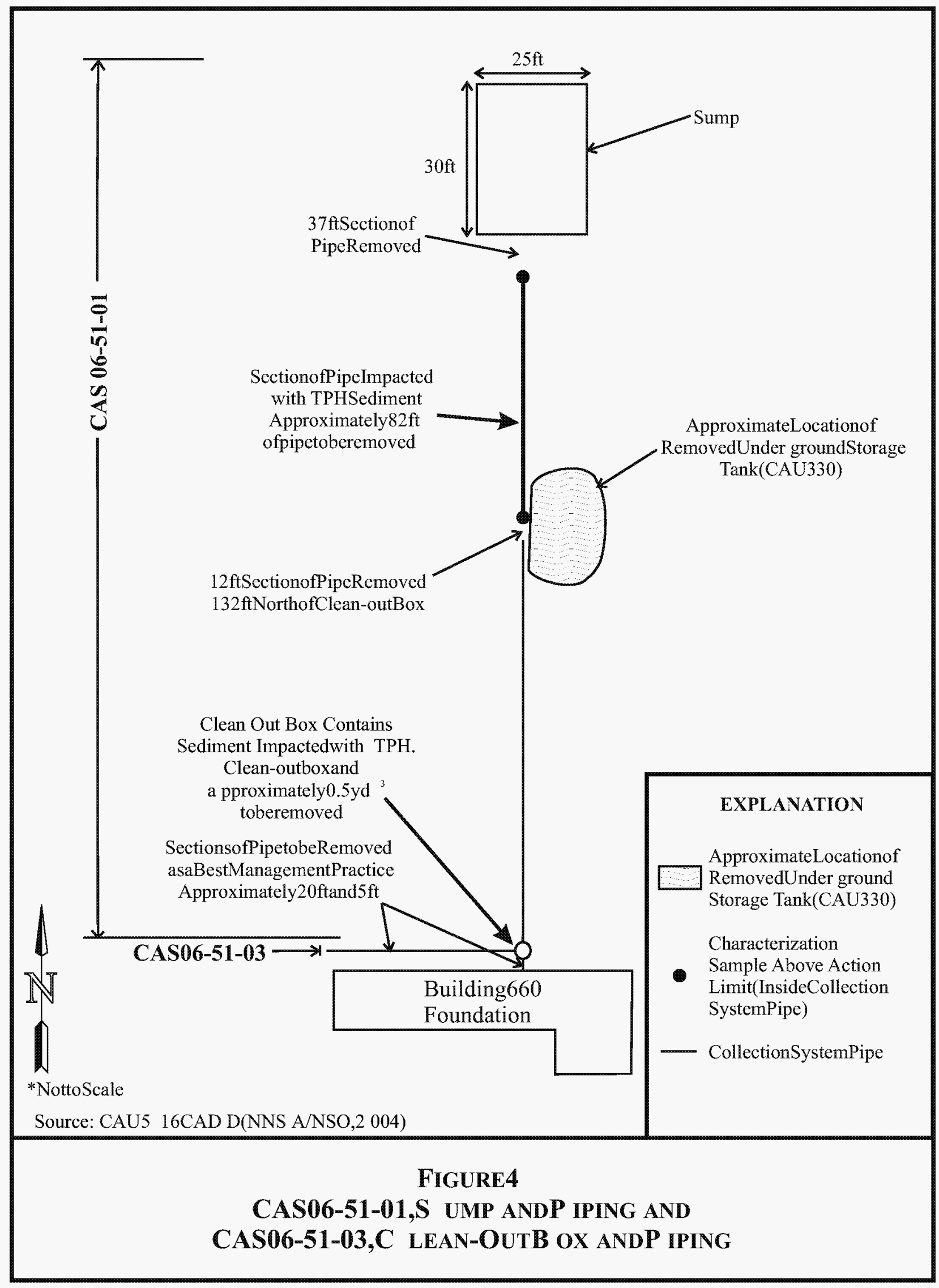


soil/sediment within the clean-out box at a concentration of $180 \mathrm{mg} / \mathrm{kg}$, which exceeds the regulatory action level of $100 \mathrm{mg} / \mathrm{kg}$ (Figure 4) (NAC, 2003). The clean-out box and approximately $0.5 \mathrm{yd}^{3}$ of soil from the clean-out box will be removed and disposed of as hydrocarbon waste in an appropriate onsite disposal facility. The associated piping is not contaminated, but as a BMP, approximately $25 \mathrm{ft}$ of piping associated with the clean-out box will be removed and disposed of as hydrocarbon waste in an appropriate onsite disposal facility. This includes $5 \mathrm{ft}$ of piping between the clean-out and Building 660 foundation and $20 \mathrm{ft}$ of pipe west of the clean-out box (Figure 4). After removal of the clean-out box, visual inspection will be conducted to ensure that visible contamination has been removed. Prior to collecting verification samples, field screening for TPH will be performed using a PetroFLAG ${ }^{\circledR}$ kit. After field screening indicates that contamination is no longer present above PALs, a minimum of five soil verification samples will be collected from excavated area of clean-out box, at least one from each side wall and one from the base of the excavation. Samples will be analyzed for TPH-DRO to verify that TPH-DRO has not been released in the soil. NTS native fill will be used to backfill excavations.

\subsection{CONSTRUCTION QUALITY ASSURANCE / QUALITY CONTROL}

Construction activities are limited to excavation, backfilling, solidifying, and removing liquids from septic tanks, removal of distribution boxes, septic tanks, and associated piping. No engineered structures will be constructed as part of site closure. Therefore, a construction quality assurance/quality control (QA/QC) plan is not required.

\subsubsection{Construction Field Sample Collection Activities}

Construction field samples are not necessary for the closure of the CASs listed in this CAP, although field sample collection activities and radiological surveys will be conducted to verify that clean up criteria have been met for CAS 03-59-01 (Building 3C-36 Septic System); CAS 03-59-02 (Building 3C-45 Septic System); CAS 06-51-01, Sump and Piping), and CAS 06-51-03 (Clean-Out Box and Piping). Field sample collection activities are addressed in Sections 2.1.2 and 2.4.

\subsubsection{Construction Laboratory/Analytical Data Quality Indicators}

CAU 516 closure activities are limited to soil removal, non-struc tural excavation and backfilling, draining of liquid from septic tanks, and removal of septic tanks, distribution boxes, and piping. Therefore, a construction QA/QC plan is not required, and construction Data Quality Indicators (DQI) are not applicable. To ensure that backfill material remains consistent, all fill will be taken from an approved NTS borrow source.

\subsection{WASTE MANAGEMENT}

All waste streams will be managed and disposed of in accordance with applicable state and federal regulations, DOE Orders, U.S. Department of Transportation, and the contractor's waste management procedures. CAU 516 closure activities are expected to generate sanitary waste/construction debris, low-level waste (LLW), hydrocarbon waste, and possibly hazardous waste, or mixed waste. Waste generated during closure activities will be properly managed and shipped to an onsite or offsite facility. Confirmation of waste disposal or transfer to BN WGS for management and disposal will be included in the CAU 516 Closure Report (CR). 


\subsubsection{Waste Minimization}

All work activities that generate waste will follow the BN Waste Minimization and Pollution Prevention Program. Special care will be given to properly characterize and segregate the waste streams to avoid the generation of additional waste.

\subsubsection{Waste Types}

\section{Sanitary Waste}

Sanitary waste (e.g., non-impacted personal protective equipment [PPE] and general trash) and construction debris (e.g., wood, concrete, block, metal, plastic) removed from the site will be screened for free release (U.S. Department of Energy, Nevada Operations Office [DOE/NV], 2000) and disposal. Sanitary waste will be disposed of in an onsite permitted landfill.

\section{Hydrocarbon Waste}

All solidified hydrocarbon waste will be analyzed for gamma-emitting radionuclides by either ISOCS or laboratory analysis, in order to satisfy the landfill disposal restrictions. Upon receipt of the analytical results, the waste will be properly characterized and disposed. Any waste meeting the land disposal restrictions as specified in the land fill permit will be disposed in the Area 6 Hydrocarbon Landfill. Hydrocarbon waste not meeting the landfill disposal restrictions will be stored in a waste accumulation area until a disposal path is identified.

\section{Hazardous Waste}

It is anticipated that a limited quantity of hazardous waste will be generated during clean closure activities for CAS 03-59-02 (Building 3C-45 Septic System). The waste will be characterized by sampling, and a waste profile for disposal will be prepared. The waste will be managed and disposed according to all applicable $\mathrm{BN}$ procedures and state and federal regulations. Containers of waste will be stored in an appropriate waste accumulation area. Upon generation, the waste shall be containerized and stored in a satellite accumulation area or a 90-Day Hazardous Waste Accumulation Area depending on the amount of waste generated. After an approved waste profile is generated, the waste will be disposed of at an appropriate permitted TSD facility.

\section{Mixed Waste}

Mixed waste may be generated during closure activities and will be managed and disposed of in accordance with all applicable BN and NNSA/NSO procedures and regulations.

\section{Low-Level Waste}

Closure activities may include removal of radiologically contaminated soil with TPH-DRO. The waste will be characterized by process knowledge, laboratory analysis, and/or radiological screening; a profile for disposal will be prepared. Based on radioactivity levels, the waste may be classified as hydrocarbon waste or LLW. If LLW is generated, it will be stored in a radioactive materials area and packaged in approved containers, if required. After approval of the waste profile, the LLW will then be transported to an appropriate onsite disposal facility and disposed. All LLW will be properly characterized by BN WGS. All LLW shall be managed and disposed in accordance with BN Organization Procedure (OP) OP-2151.304, "Radioactive Waste 
Tracking, Handling, and Management at the NTS" (BN, 2004a), and all applicable state and federal regulations. All LLW will be packaged in the presence of a Waste Certification Official and WGS personnel according to OP-2151.304 (BN, 2004a). LLW will be stored in a radioactive materials area until transport to an appropriate disposal facility can be arranged.

\section{Decontamination Waste}

All radiologically-impacted equipment will be surveyed prior to release from the exclusion zone. Any equipment that becomes contaminated during closure activities will be decontaminated onsite. Dry decontamination will be the preferred method. For larger pieces of equipment that cannot be effectively decontaminated using dry decontamination techniques, wet decontamination techniques shall be used. All decontamination rinsate will be managed appropriately in accordance with all applicable regulations and once characterized, properly disposed.

\section{Personal Protective Equipment}

All PPE that becomes contaminated during closure activities shall be disposed with the appropriate waste stream. All wastes generated during closure activities will be properly disposed in either onsite landfills or at a permitted offsite TSD facility.

\subsection{CONFIRMATION OF CORRECTIVE ACTIONS}

Accurate and defensible analytical data will be collected to characterize waste and verify that the closure objectives outlined in this CAP have been met.

\subsubsection{No Further Action Sites}

At two CASs no COC were found and the sites will be closed by taking no further action. The final site condition of these two CASs will be verified by visual inspection and photographic documentation. These CASs include:

- CAS 06-51-02 Clay Pipe and Debris. Housekeeping debris was removed during the correction actions investigation; no environmental waste or concerns remain.

- CAS 22-19-04 Vehicle Decontamination Area. No COC were identified at this CAS.

\subsubsection{Clean Closure Sites}

Section 2.1.2 provides information on verification samples required for the following CASs:

- 03 -59-01 Building 3C-36 Septic System

- 03-59-02 Building 3C-45 Septic System

- 06-51-01 Sump and Piping

- 06-51-03 Clean-Out Box and Piping

The site will be considered clean closed after laboratory results verify that verification samples are below the applicable action levels. In addition, removal of materials will be confirmed by visual inspection and photographic documentation of final site conditions. 


\subsubsection{Sample Collection Methods}

All samples will be collected by qualified BN Environmental Restoration personnel. Samples will be collected by hand, using disposable pre-cleaned or decontaminated sampling equipment (BN, 2000a). Samples will be collected either by hand from the indicated locations, or if the excavation poses a safety hazard to sampling personnel, from the center of a backhoe bucket of soil collected from the indicated locations. Liquid samples will be collected using a dipper or other transfer devices (BN, 2003a). Sludge samples from the bottom of a tank will be collected using a scoop attached to a pole or equivalent (BN, 2003a). Sample collection date, time, and other pertinent information will be logged on a "Chain of Custody" form and in a bound project field notebook. Sample traceability is established and maintained by completing a "BN Service Request and Chain of Custody Record" form (BN, 2002).

All samples will be collected in clean containers, labeled appropriately, sealed with a tamperproof seal, bagged, placed on ice in a cooler, and transported to the BN Environmental Technical Services group under a BN "Sample Chain of Custody" form (BN, 2000b). BN Environmental Technical Services group will be responsible for sample management and shipment of the samples to an approved offsite laboratory for analysis. Samples will be analyzed by U.S. Environmental Protection Agency (EPA) -approved analytical methods at EPA-approved laboratories (EPA, 1996). Sample analysis will include laboratory analysis of QA/QC samples and will follow stringent QA/QC procedures (EPA, 1996). Sample analysis for radionuclides will be performed in accordance with Environmental Measurements Laboratory Procedures Manuals (DOE, 1997).

All samples will be labeled with a unique sample identification number using the CAS number followed by the sample number (e.g., 035901-V1). Waste characterization samples will be named by using the CAS number followed by the sample number (e.g., 035901-WC1).

One set of QA/QC samples will be collected for every 20 environmental samples or one per sample batch. QA/QC samples will include blind duplicates, matrix spike/matrix spike duplicates, and trip blanks for TCLP VOCs. The blind duplicate will be labeled with a unique sample number.

\subsubsection{Laboratory/Analytical Data Quality Indicators}

Data Quality Objectives (DQO) are qualitative and quantitative statements that specify the quality of the data required to support closure of a site. The DQO for the CAU 516 site investigation were defined in the CAIP (NNSA/NSO, 2003) using the Seven Step DQO Process developed by the EPA (EPA, 2000). Three Conceptual Site Models for the CAU 516 CASs were defined in the CAIP (NNSA/NSO, 2003) and these models were reconciled with the results of the site investigation in the CADD (NNSA/NSO, 2004) (See Appendix A of the CADD). Sample analytical results will be generated during closure activities for CAS 03 -59-01 (Building 3C-36 Septic System), CAS 03-59-02 (Building 3C-45 Septic System), CAS 06-51-01 (Sump and Piping), and CAS 06-51-03 (Clean-Out Box and Piping). These CASs will be clean closed and will require the collection and analysis of verification soil samples. All laboratory data generated during closure activities will be reviewed by project personnel to ensure the data are usable and complete according to the CAU 516 DQO. In addition, as specified in the Industrial Sites Quality Assurance Project Plan (NNSA/NV, 2002), 100 percent of the final data 
packages for verification samples will be evaluated at the Tier I and Tier II levels using applicable BN Organization Instructions (OIs). These include OI-2151.303 (BN, 2004b) for validating radiological data, and OI-2154.459 (BN, 2003b) for validating inorganic chemical data. Organization Instruction OI-2154.459 is based on EPA Functional Guidelines (EPA, 2002). Any data determined not to be valid will be identified in the CR. More details on the proposed number and location of the verification samples are given in Section 2.1.2 of this plan.

DQI are qualitative and quantitative statements that specify the data requirements of a project. The DQI include accuracy, precision, comparability, completeness, representativeness, and sensitivity. These DQI are discussed below.

\section{Precision}

Precision is a measure of agreement among a replicate set of measurement of the same property under similar conditions. This agreement is expressed as the relative percentage difference (RPD) between duplicate measurements (EPA, 1996). Precision applies to parameters sampled and analyzed in duplicate.

One duplicate sample will be collected per set of 20 or fewer verification samples. All duplicate samples will be collected from the same medium and analyzed for the same set of analytes as verification samples. The precision of the analytical results will be assessed by calculating the RPD for a verification sample and its duplicate sample results. An RPD of less than or equal to 30 percent indicates acceptable precision (NNSA/NV, 2002).

\section{Accuracy}

Accuracy is a measure of the closeness of an individual measurement or the average of a number of measurements to the true value. Accuracy includes a combination of random error (precision) and systematic error (bias) components that result from sampling and analytical operations. This closeness is expressed as percent recovery (\%R) (EPA, 1996). Accuracy will be assessed by examining the $\% \mathrm{R}$ of laboratory control and spiked samples. $\mathrm{A} \% \mathrm{R}$ within the range of 70 to 130 percent indicates satisfactory analytical accuracy (NNSA/NV, 2002).

\section{Representativeness}

Representativeness is a qualitative evaluation of measurement system performance. It is the degree to which sample data accurately and precisely represent a characteristic of a population, parameter variations at a sampling point, or an environmental condition (EPA, 1996).

Representativeness will be attained by ensuring that the sample locations, analytical parameters, analytical methods, sampling protocols, and sample handling all meet the project-specific objectives.

\section{Comparability}

Comparability is a qualitative measure that expresses the confidence that one data set can be compared to another. It will be achieved by using standardized field sampling procedures. The same analytical laboratory will perform the same analyses for all samples. Sample results will be reported in standard units to allow for comparison of the data. 


\section{Completeness}

Completeness is a quantitative measure of data quality expressed as the percentage of valid data obtained that satisfies the project-specific requirements. Since a limited number of samples will be collected for both waste characterization and verification of closure, 100 percent of the data collected needs to be of acceptable quality to maintain acceptable QA/QC standards.

\section{Sensitivity}

Sensitivity is the capability of a method or instrument to discriminate between measurement responses representing different levels of a variable of interest. This indicator is determined from the value of the standard deviation at the concentration level of interest. It represents the minimum difference of concentration that can be distinguished between two samples with a high degree of confidence. Sensitivity must be sufficient to detect contaminants at or below decision levels. Sensitivity will be achieved by analyzing all samples using appropriate EPA-approved analytical laboratories, methods, and instruments.

\subsection{PeRMits}

Prior to beginning field closure activities, planning documents and permits will be prepared. These documents will include a Field Management Plan, National Environmental Policy Act (NEPA) Checklist, NNSA/NSO Real Estate/Operations Permit (REOP), Radiological Work Permit (RWP), BN Work Packages, excavation permits, and blind penetration permits.

\subsubsection{National Environmental Policy Act Checklist}

A NEPA Checklist will be completed prior to all excavation activities at the site. Excavation activities will follow all applicable federal, state, and local laws, regulations, and permits regarding protection of the environment.

\subsubsection{NNSA/NSO Real Estate/Operations Permit}

$\Lambda$ REOP will be obtained prior to beginning closure activities. The permit will establish the NNSA/NSO as the prime authority possessing control of the site.

\subsubsection{Radiological Work Permit}

RWPs will be required for work at any radiologically-impacted site when radiological conditio ns require, as determined by BN Health Physics. RWPs will inform workers of the specific PPE necessary to protect them while performing their tasks and identify site-specific controls. The workers will be required to sign the permits and acknowledge their understanding of the requirements before entry into any contamination area, if present. The RWPs will be maintained by the Radiological Control Technician at the entrance to the contamination area. All site workers will be required to be Radiation Worker II trained to perform any work within a radiologically controlled area.

\subsubsection{Utility Clearances, Excavation Permits, and Blind Penetration Permits}

An excavation permit and a blind penetration permit will be obtained prior to beginning any excavation activities. These permits require that a utility clearance be performed. A copy of the permit will be filed on site throughout the duration of the project. 
Revision: 0

Date: August 2005

THIS PAGE INTENTIONALLY LEFT BALNK 


\subsection{SCHEDULE}

All preparation and field activities are scheduled for completion in Fiscal Year 2006. The FFACO deadline for the CR has not yet been established. Sufficient flexibility has been incorporated into the field schedule to allow for minor difficulties (e.g., weather, equipment failure). The NNSA/NSO shall notify the NDEP of any condition or event that may impact the project schedule. 
CAP - CAU 516

Section: Schedule

Revision: 0

Date: August 2005

THIS PAGE INTENTIONALLY LEFT BLANK 


\subsection{POST-CLOSURE PLAN}

The approved Corrective Action is Alternative 1 - No Further Action for the CAS 06-51-02 and CAS 22-19-04; therefore, no post-closure monitoring is required. For CAS 03-59-01, CAS 03-59-02, CAS 06-51-01, and CAS 06-51-03, the approved Corrective Action is Alternative 2 - Clean Closure and no post-closure monitoring or site inspections are required.

\subsection{INSPECTIONS}

No post-closure inspection will be required as all CASs will be clean closed or by taking no further action.

\subsection{MONITORING}

As no sampling or collection of data will be performed after closure of the CAU, no post-closure monitoring is required for these CASs.

\subsection{MAINTENANCE AND REPAIR}

CAU 516 will be clean closed; therefore, no post-closure maintenance or repairs will be required. 
CAP - CAU 516

Section: Post-Closure Plan

Revision: 0

Date: August 2005

THIS PAGE INTENTIONALLY LEFT BLANK 


\subsection{REFERENCES}

BN, see Bechtel Nevada.

Bechtel Nevada. 2000a. "Soil Sampling," Organization Instruction OI-2152.108, Revision 0. Las Vegas, NV.

Bechtel Nevada. 2000b. "Sample Chain of Custody," Organization Instruction OI-2152.100, Revision 0. Las Vegas, NV.

Bechtel Nevada. 2002. "Service Request and Chain of Custody Record," BN-0732. Las Vegas, NV.

Bechtel Nevada. 2003a. "Soil, Waste, and Water Sampling for Characterization and Compliance," Organization Instruction OI-2154.120, Revision 0. Las Vegas, NV.

Bechtel Nevada. 2003b. "Inorganic Data Verification and Validation" Organization Instruction OI-2154.459. Las Vegas, NV.

Bechtel Nevada. 2004a. "Radiological Waste Tracking, Handling, and Management at the NTS," Organization Procedure OP-2151.304, Revision 5. Las Vegas, NV.

Bechtel Nevada. 2004b. "Validation of Radiological and Chemical Laboratory Data," Organization Instruction OI-2151.303. Las Vegas, NV.

Code of Federal Regulations. 2002. Title 40 CFR 261, "Identification and Listing of Hazardous Waste." Washington, D.C.

DOE, see U.S. Department of Energy.

DOE/NV, see U.S. Department of Energy/Nevada Operations Office.

EPA, see U.S. Environmental Protection Agency.

FFACO, see Federal Facility Agreement and Consent Order.

Federal Facility Agreement and Consent Order. 1996 (as amended). Agreed to by the State of Nevada, the U.S. Department of Energy, and the U.S. Department of Defense.

NAC, see Nevada Administrative Code.

Nevada Administrative Code. 2003. NAC 445A.2272, "Contamination of Soil: Establishment of Action Level" Carson City, NV.

NCRP, see National Council on Radiation Protection and Measurements. 
NDEP, see Nevada Division of Environmental Protection.

NNSA/NSO, see U.S. Department of Energy, National Nuclear Security Administration Nevada Site Office.

NNSA/NV, see U.S. Department of Energy, National Nuclear Security Administration Nevada Operations Office.

National Council on Radiation Protection and Measurements. 1999. Recommended Screening Limits for Contaminated Surface Soil and Review of Factors Relevant to Site-Specific Studies, NCRP Report Number 129, Bethesda, MD.

Nevada Division of Environmental Protection. 2004. Review of Industrial Sites Project Document "Calculating Industrial Sites Project Remediation Goals for Radionuclides in Soil Using the Residual Radiation (RESRAD) Computer Code," Letter from Tim Murphy (Chief for the Bureau of Federal Facilities) to Robert Bangerter (Acting Director Environmental Restoration Division) dated November 19, Las Vegas, NV.

Nevada Division of Environmental Protection. 2005. Second Extension of the Water Pollution Control General Permit GNEV 93001 to Facilitate Lining of Area 23 Mercury Lagoon System, Nevada Test Site, Letter from Tim Murphy (Chief for the Bureau of Federal Facilities) to Kenneth A Hoar (Director Environmental, Safety \& Health Division, Nevada Nuclear Security Administration) dated April 18, Las Vegas, NV.

U.S. Department of Energy. 1997. Environmental Measurements Laboratory Procedures Manual, HASL-300, $28^{\text {th }}$ Ed., Vol. 1. New York, NY.

U.S. Department of Energy, National Nuclear Security Administration Nevada Operations Office. 2002. Industrial Sites Quality Assurance Project Plan, Nevada Test Site, Nevada, Rev. 3, DOE/NV--372. Las Vegas, NV.

U.S. Department of Energy, National Nuclear Security Administration Nevada Site Office. 2003. Corrective Action Investigation Plan for Corrective Action Unit 516: Septic Systems and Discharge Points, Nevada Test Site, Nevada, DOE/NV-889-Rev. 0, Las Vegas, NV.

U.S. Department of Energy, National Nuclear Security Administration Nevada Site Office. 2004. Corrective Action Decision Document for Corrective Action Unit 516: Septic Systems and Discharge Points, Nevada Test Site, Nevada, DOE/NV-957-Rev.1, Las Vegas, NV. 


\section{REFERENCES (continued)}

U.S. Department of Energy, Nevada Operations Office. 2000. NV/YMP Radiological Control Manual Rev. 4, DOE/NV/11718-079. Las Vegas, NV.

U.S. Environmental Protection Agency. 1996. Test Methods for Evaluating Solid Waste Physical/Chemical Methods, SW-846, Third Edition. Washington, D.C.

U.S. Environmental Protection Agency. 2000. Guidance for Data Quality Assessment: Practical Methods for Data Analysis, EPA QA/G-9, EPA/600/R-96/055. Washington, D.C.

U.S. Environmental Protection Agency. 2002. Contract Laboratory Program National Functional Guidelines for Inorganic Data Review, EPA/540/R-94/013. Washington, D.C. 
Revision: 0

Date: August 2005

THIS PAGE INTENTIONALLY LEFT BLANK 


\section{APPENDIX A.1}

\section{ENGINEERING SPECIFICATIONS AND DRAWINGS}

NOTE: Engineering specifications and drawings are not required for closure of CAU 516. This Appendix is included here as required by the approved Federal Facility Agreement and Consent Order outline for a Corrective Action Plan. 
Revision: 0

Date: August 2005

THIS PAGE INTENTIONALLY LEFT BLANK 


\section{APPENDIX A.2}

\section{SAMPLING AND ANALYSIS PLAN}

NOTE: Sufficient details on the type, number, and location of verification samples to be collected to verify site closure activities have been provided in Sections 2.1.2 and 2.4. This Appendix is included here as required by the approved Federal Facility Agreement and Consent Order outline for a Corrective Action Plan. 
Revision: 0

Date: August 2005

THIS PAGE INTENTIONALLY LEFT BLANK 
CAP - CAU 516

Section: Appendix A.3

Revision: 0

Date: August 2005

\section{APPENDIX A.3}

\section{Project ORganization}

A.3-1 
CAP - CAU 516

Section: Appendix A.3

Revision: 0

Date: August 2005

THIS PAGE INTENTIONALLY LEFT BLANK

A.3-2 


\section{PROJECT ORGANIZATION}

The U.S. Department of Energy, National Nuclear Security Administration Nevada Site Office (NNSA/NSO) points of contact for this project are as follows:

NNSA/NSO Acting Project Manager: Sabine Curtis

Telephone Number: (702) 295-0542

NNSA/NSO Task Manager: Kevin Cabble

Telephone Number: (702) 295-5000

The identification of the project Health and Safety Officer and the Quality Assurance Officer can be found in the appropriate plan. However, personnel are subject to change and it is suggested that the appropriate U.S. Department of Energy Project Manager be contacted for further information. The Task Manager will be identified in the Federal Facility Agreement and Consent Order Monthly Activity Report prior to the start of field activities. 
CAP - CAU 516

Section: Appendix A.3

Revision: 0

Date: August 2005

THIS PAGE INTENTIONALLY LEFT BLANK 
CAP - CAU 516

Section: Distribution

Revision: 0

Date: May 2005

\section{LIBRARY DISTRIBUTION LIST}


CAP - CAU 516

Section: Distribution

Revision: 0

Date: May 2005

THIS PAGE INTENTIONALLY LEFT BLANK 


\section{LIBRARY DISTRIBUTION LIST}

U.S. Department of Energy

National Nuclear Security Administration

Nevada Site Office

Technical Library

P.O. Box 98518, M/S 505

Las Vegas, NV 89193-8518

U.S. Department of Energy

Office of Scientific and Technical Information

P.O. Box 62

Oak Ridge, TN 37831-0062

Southern Nevada Public Reading Facility

c/o Nuclear Testing Archive

P.O. Box 98521, M/S 400

Las Vegas, NV 89193-8521

Manager, Northern Nevada FFACO

Public Reading Facility

c/o Nevada State Library \& Archives

Carson City, NV 89701-4285
1 (Uncontrolled)

1 (Uncontrolled, electronic copy)

1 (Controlled)

1 (Uncontrolled)

1 (Uncontrolled) 
CAP - CAU 516

Section: Distribution

Revision: 0

Date: May 2005

THIS PAGE INTENTIONALLY LEFT BLANK 